\title{
ACTIVE REPLICATION OF HEPATITIS B VIRUS (HBV) IN HIV TYPE 1 AND IN HIV TYPE 2 INFECTED PATIENTS
}

\author{
M.F. BARROS(1), J. PIEDADE(2), G. NUNES(1), W. CANAS-FERREIRA(2), A.P. SILVA(4), J.L. CHAMPALIMAUD(3) \& \\ J.A. MACHADO-CAETANO(1)
}

\begin{abstract}
SUMMARY
To evaluate the effect of concurrent infection by HIV on HBV infection or immunity, we have studied a group of 66 HIV1+ symptomatic Caucasian patients and another of 38 African HIV2+ asymptomatic individuals, concerning their HBV status: serological markers of infection and presence of HBV-DNA in serum, the last taken as sign of hepatitis B virus active replication, were monitored. $\mathrm{HIV}+$ groups were compared with seronegative controls, adequately matched for age, sex and ethnological background.

HBV DNA was found in $7.6 \%$ of HIV 1+ Caucasian patients and $3.2 \%$ of seronegative controls; in African HIV $2+$ individuals $2.6 \%$ were also HBV DNA+, a percentage close to that found in HIV2 seronegative controls $(2.9 \%)$.

No correlation was found between HIV infection and HBV active replication. Immunodepression that follows HIV infection over time may be compatible with a degree of $\mathrm{T}$ cell function capable of avoiding reinfection with or reactivation of $\mathrm{HBV}$, even in symptomatic stages of acquired immunodeficiency syndrome. Our findings are relevant to the choice of preventive strategies in populations at risk for HIV and HBV infection.
\end{abstract}

KEYWORDS: HIV; HBV active replication.

\section{INTRODUCTION}

Hepatitis B virus $(\mathrm{HBV})^{10}$ and human immunodeficiency virus (HIV) ${ }^{2,9}$ share parenteral and sexual modes of transmission, so risk factors for both viruses are similar, coinfection may be frequent and interaction between HIV and HBV possible: $-X$ protein coded by an open reading frame in HBV genome may transactivate HIV long terminal repeats ${ }^{1,2,27}$ and stimulate HIV replication; - T cell impairment subsequent to HIV infection may influence the outcome of viral hepatitis. In fact, a higher rate of progression to chronicity after HIV infection has been observed in HBV patients ${ }^{16}$ as well as diminished responsiveness to recombinant $\alpha$ interferon therapy ${ }^{23}$. However, reports of HBV reactivation or reinfection during HIV infection are rare $^{14,2 x}$.

An increased expression of HBV surface and core antigens in hepatocytes from chronically infected patients who were also HIV+ ${ }^{15.24}$ - although with no diffe-

(1) Serviço de Imunologia, Faculdade de Ciências Médieas, Universidade Nova de Lisboa (UNL), Portugal.

(2) Departamento de Microbiologia, Instituto de Higiene e Medicina Tropical (IHMT), Universidade Nova de Lisboa (UNL),

(3) Unidade de Doenças Infecciosas, Hospital Egas Moniz (IHMT, UNL).

(4) Ministério da Saúde, República da Giné-Bissau.

Correspondence to: M.F. Barros. Departamento de Imunologia, Faculdade de Ciências Médicas (UNL), Campo de Santana 130, 1100 Lisboa, Portugat. 
rence in HBV circulant DNA - could be ascribed to T cell dysfunction, even in asymptomatic subjects ${ }^{15}$, but other factors may also be involved as time of first contact to HBV or duration of previous chronic infection ${ }^{21}$.

In mitogen stimulated peripheral blood mononuclear cells, detection of HBV DNA sequences after enzymatic amplification has been reported but with conflicting results concerning correlation to HIV status ${ }^{\mathrm{x}, 11}$.

In patients from Central Africa, no difference was found in HBsAg expression between HIV+ and HIV negative individuals, in spite of pre-s2 antigen may be more frequent among those who are $\mathrm{HIV}+{ }^{20}$. In Europe, a recent study of prevalence of different viral hepatitis markers in HIV+ patients also failed to notice any difference concerning HBV serological markers and HIV infection ${ }^{13}$.

We have studied two different groups of HIV infected individuals: one of HIV 1+ Caucasian patients, the large majority of which were symptomatic (66 out of $82,80.5 \%$ ) and living in Portugal and another of HIV $2+$ African asymptomatic subjects, residents in GuineaBissau, a region where HIV and HBV are both endemic, in order to assess the effect of coinfection with HIV: (1) in the course of HBC infection; (2) in previously established immunity.

HIV + patients were compared to control seronegative groups from the same geographical origin and ethnological background, concerning serological markers of $\mathrm{HBV}$ infection and the presence of circulant HBV DNA, considered as sign of active HBV replication, which correlation with $\mathrm{HBe}$ antigen expression is well known for several years ${ }^{5,26,29}$, being a marker of much higher sensitivity ${ }^{19}$.

\section{PATIENTS AND METHODS}

Characteristics of the different groups studied (patients and controls) are summarized in Table 1.

All patients gave an informed agreement to participate in this study and samples obtained from $5 \mathrm{ml}$ of blood were kept, cyphered and anonymous, at $-20^{\circ} \mathrm{C}$ until use.

HIV antibodies and HBV antibodies or antigens were detected using commercial enzyme linked immunosorbent assays (ELISA) (Cambridge Biotec. Corp. and Abbot, respectively). HIV positive results were confirmed by Western blot (Pasteur) and or immunofluorescence assay ${ }^{17}$.

Viral DNA was prepared from $200 \mu \mathrm{l}$ of serum, incubating for 1 hour at $65^{\circ} \mathrm{C}$ in $50 \mathrm{mM}$ Tris- $\mathrm{HCl}$ buffer $\mathrm{pH}=7.5,150 \mathrm{mM} \mathrm{NaCl}, 25 \mathrm{mM}$ EDTA, 2\% SDS. $0.4 \mathrm{mg} / \mathrm{ml}$ proteinase $\mathrm{K}$ (Sigma), extracting twice with a phenol-chloroform-isoamylic alcohol mixture $(25: 24: 1)$ and ethanol precipitating at $-20^{\circ} \mathrm{C}$ in the presence of $300 \mathrm{mM}$ sodium acetate and $25 \mu \mathrm{g}$ of yeast $\mathrm{t}$ RNA (Sigma).

Precipitates were collected by centrifugation $(10,000 \mathrm{~g}$ for 30 minutes $)$ and resuspended in $50 \mu \mathrm{l}$ of $10 \mathrm{mM}$ Tris- $\mathrm{HCl} \mathrm{pH}=7.5,1 \mathrm{mM}$ EDTA or distilled water. In the first case viral DNA was detected by molecular hybridization (M.H.) using a dot-blot assay and ${ }^{32} \mathrm{P}-\mathrm{la}-$ belled cloned HBV DNA33.

For polymerase chain reaction (PCR) $)^{23}$ analysis $25 \mu \mathrm{l}$ of sample (corresponding to $100 \mu \mathrm{l}$ of serum) were amplified in a total volume of $100 \mu \mathrm{l}$ reaction mixture containing $5 \mathrm{U}$. of Taq DNA polymerase (Pharmacia),

TABLE 1

Characteristics of the different groups studied.

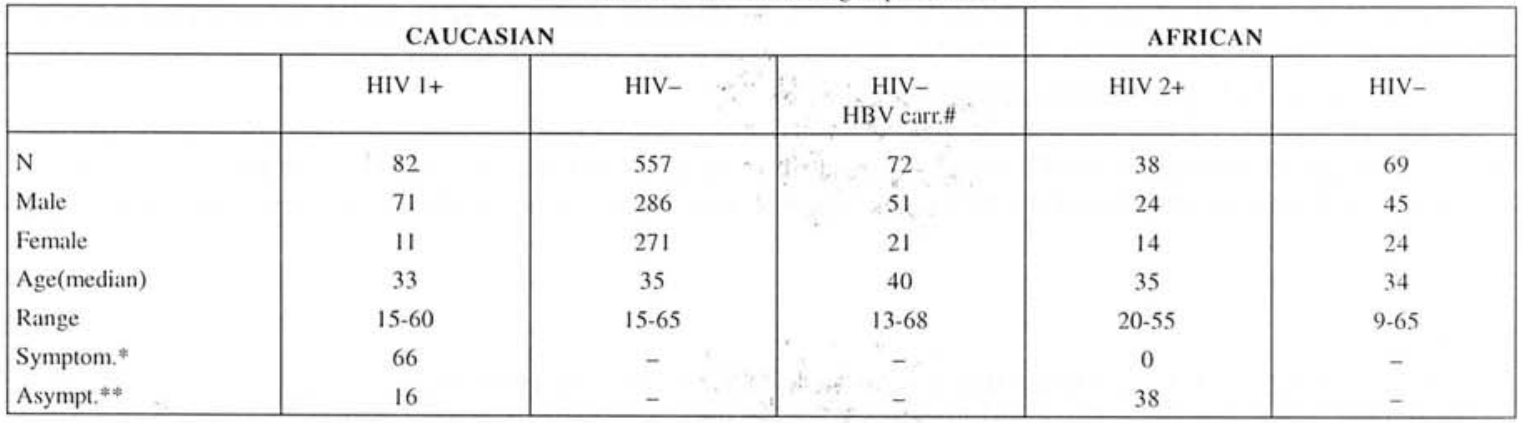

* Stages III and IV (CDC)3

tho Stage II

\# $\mathrm{HBsAg}+$, anti-HBe+for $>6$ months 
$250 \mu$ moles of each desoxiribonucleoside triphosphate, $1 \mathrm{x}$ reaction buffer (Pharmacia) and 25 pmoles of the oligonucleotide pair $^{18}$.

\section{5' GCT TTG GGG CAT GGA CAT TGA CCC GTA TAA 3' (pos 1864-1893)}

\section{5'CTG ACT ACT ATT TCC CTG GAT GCT GGG TCT 3' (pos 2133-2104)}

After 30 cycles at $94{ }^{\circ} \mathrm{C}(30 \mathrm{~s}), 45^{\circ} \mathrm{C}(60 \mathrm{~s}), 72{ }^{\circ} \mathrm{C}$ $(60 \mathrm{~s})$, following an initial denaturation period of $10 \mathrm{~min}$ utes at $94^{\circ} \mathrm{C}$ and a last incubation at $72^{\circ} \mathrm{C}$ for 7 minutes, one tenth of the reaction mixture was electrophoresed in a $2 \%$ agarose gel to check amplified DNA.

Statistical analysis was performed using $\chi^{2}$ testing.

\section{RESULTS}

Serological markers of HBV infection and presence of seric HBV DNA were evaluated in 82 HIV $1+$ patients (66 symptomatic and 16 asymptomatic) and 557 HIV negative controls, adequately matched considering age and sex, as well as in 38 HIV $2+$ individuals and 69 HIV negative controls from Guinea-Bissau.

Amongst Caucasian HIV 1+ symptomatic patients, according to C.D.C. classification? 11 (16.7\%) were also $\mathrm{HBsAg}+$ and in $5(7.6 \%)$ HBV DNA was found in serum. These percentages are higher than those found in HIV negative control blood donors ( $\mathrm{HBsAg} 8.1 \%$, HBV DNA $3.2 \%$ ) but the difference is not statistically significant $(p>0.1)$. However, the number of sera positive for anti-HBc antibodies is much higher in $\mathrm{HIV} 1+$ patients $(72.7 \%)$ than in negative controls $(22.4 \%)$ as can be seen in Table $2(p<0.01)$. No HBsAg+ or DNA+ sera was found in asymptomatic individuals.
In African HIV $2+$ patients, 7 (18.4\%) were $\mathrm{HBsAg}+$ and $1(2.6 \%)$ HBV DNA+, percentages that did not significantly differ from those in HIV negative control population (30.4 and $2.9 \%$, respectively). Anti-HBc antibodies were present in $35(92.1 \%)$ of African HIV $2+$ and $62(89.9 \%)$ of HIV negative sera.

As it is also shown in Table 2 about $50 \%$ of $\mathrm{HBsAg}+$ sera from Portugal are HBV DNA+, either in HIV I+ patients or HIV negative controls, asymptomatic blood donors and HBV chronic carriers. Although there is a slightly higher frequency in the HIVI+ group $(54.5 \%)$ than in the HIV negative (40\%), this was not statistically significant. Further subclassification on symptomatic vs. asymptomatic HIV1+ was not possible due to the small amount of cases in these categories. In groups from Guinea-Bissau a lower percentage of $\mathrm{HBsAg}$ DNA+ carriers was found $(14.3 \%$ in $\mathrm{HIV} 2+$ sera and $9.5 \%$ in $\mathrm{HIV}$ negative controls).

HBV DNA was detected by M.H. (Figure 1) and PCR (Figure 2) in all sera positive for $\mathrm{HBe}$ antigen, but only through $\mathrm{PCR}$ in $\mathrm{HBe}$ negative sera positive for anti$\mathrm{HBe}$, with the exception of I sample from $\mathrm{HIV} 2+$ patients which was also detected by M.H., as well as in 14 samples from HIV negative HBV carriers, using probes which sensitivity went down to 2.5 to $5 \mathrm{pg}$ of $\mathrm{HBV}$ DNA/ml serum (Figure 1).

\section{DISCUSSION}

No strong correlation was found between active HBV replication and HIV infection, either in HIV I+ symptomatic Caucasian patients or in HIV2+ asymptomatic African individuals. Symptomatic and asymptomatic patients were considered in an attempt to study individuals with a different degree of immunodeficiency, infected by one of the two known HIV types and

TABLE 2

HBV markers in the different groups studied.

\begin{tabular}{|c|c|c|c|c|c|c|}
\hline \multirow{2}{*}{$\mathrm{N}$} & \multicolumn{2}{|c|}{ HIV1+ } & \multirow{2}{*}{$\begin{array}{l}\text { HIV- } \\
557\end{array}$} & \multirow{2}{*}{$\begin{array}{c}\text { HIV- } \\
\text { HBV carriers }\end{array}$} & \multirow{2}{*}{$\begin{array}{c}\text { HIV } 2+ \\
38\end{array}$} & \multirow{2}{*}{$\begin{array}{c}\text { HIV- } \\
69\end{array}$} \\
\hline & $66^{*}$ & $16^{* *}$ & & & & \\
\hline Anti-HBct & 48 & 8 & 125 & 72 & 35 & 62 \\
\hline $\mathrm{HBsAg}+$ & 11 & 0 & 45 & 72 & 7 & 21 \\
\hline $\mathrm{HBeAg}+$ & 2 & 0 & 13 & 0 & 0 & 1 \\
\hline DNA (MH/PCR) & 2 & 0 & $13(\mathrm{~s}+\mathrm{e}+)$ & $14(s+\alpha c+)$ & $1(s+\alpha e+)$ & $1(s+e+)$ \\
\hline DNA (PCR) & 3 & 0 & $5(s+\alpha e+)$ & $18(s+\alpha e+)$ & 0 & $1(s+\alpha c+)$ \\
\hline Total & 5 & 0 & 18 & 32 & 1 & 2 \\
\hline $\mathrm{DNA} / \mathrm{s}+$ & $54.5 \%$ & - & $40 \%$ & $44.4 \%$ & $14.3 \%$ & $9.5 \%$ \\
\hline
\end{tabular}

* symptomatic

** asymptomatic 


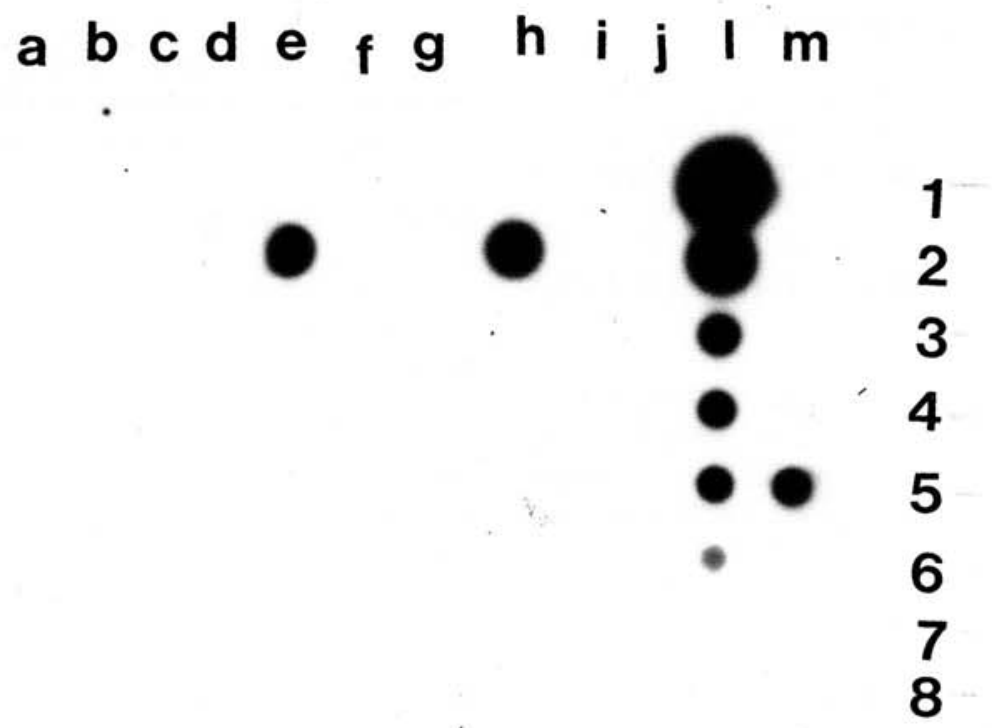

Fig. 2 - Amplification of HBV DNA sequences from HBsAg+ HIVI+ samples (269bp). Lanes a and b: DNA size markers (189bp and 599bp).

that could have been exposed to HBV at different periods of their lives.

No significant increase in $\mathrm{HBs}$ Ag and HBV DNA carriers was evident in HIV infected individuals when HBV DNA was tested using the most sensitive methods presently available: molecular hybridization and PCR.

PCR with a set of primers localized in the core region of HBV genome enabled us to evidence viral DNA in 40 to $45 \%$ of $\mathrm{HBsAg}+$ sera what is in agreement with other results known, considering not only $\mathrm{HBeAg}+$ sera but all $\mathrm{HBsAg}+$ sera and as it is evident in the group of HIV negative HBV carriers, all of them anti-HBe antibody positive and selected with the aim of comparing HIV patients with a population in which $\mathrm{T}$ cell response could be non efficient due to escape or $\mathrm{T}$ cell antagonist viral mutants ${ }^{4,6}$.

In $\mathrm{HIV}+$ patients, the percentage of $\mathrm{HBeAg}+$ sera was low and coincident with DNA detection by molecular hybridization and PCR. PCR, as expected for a more sensitive method, allowed further detection of DNA+ samples, all of them with $\mathrm{s}+\mathrm{antiHBe}+$ markers.

A lower percentage of DNA+ samples amongst $\mathrm{HBsAg}+$ was found in African patients, it is temptative to speculate that escape mutants would be rare and $\mathrm{T}$ cytotoxic cells capable of a complete clearance of infected hepatocytes, but only a larger number of DNA positive samples would allow a valid analysis of viral mutants.

Results obtained in sera from Guinea-Bissau reflect the epidemiologic pattern of infection by HBV during childhood and a latter contact with HIV in adult life, as it is known for other regions of Africa ${ }^{12}$. Although a slower pregression to full blown AIDS has been claimed for HIV2, maintenance of T cell surveillance sufficient to avoid reactivation and prevent HBV reinfection may also be present in HIVl infected patients, even in symptomatic stages of immunodeficiency progression as shown by our results and rare reports of $\mathrm{HBV}$ reactivation or reinfection.

In Caucasian Portuguese patients, the difference in anti-HBc antibodies found between HIV+ and HIV negative controls is in favour of a contact with $\mathrm{HBV}$ and HIV that may be more or less simultaneous and related with sexual behaviour. However, as HBV is more contagious and has been prevalent in risk populations for a longer time than HIV, it is possible that HBV infection has preceded HIV1 infection and so hepatitis outcome has not been influenced by severe immunodepression.

Our results strength the need of screening HIV + patients for markers of HBV infection in order to:

- Prevent further dissemination of HBV in groups at risk and particularly vulnerable to an unfavourable 


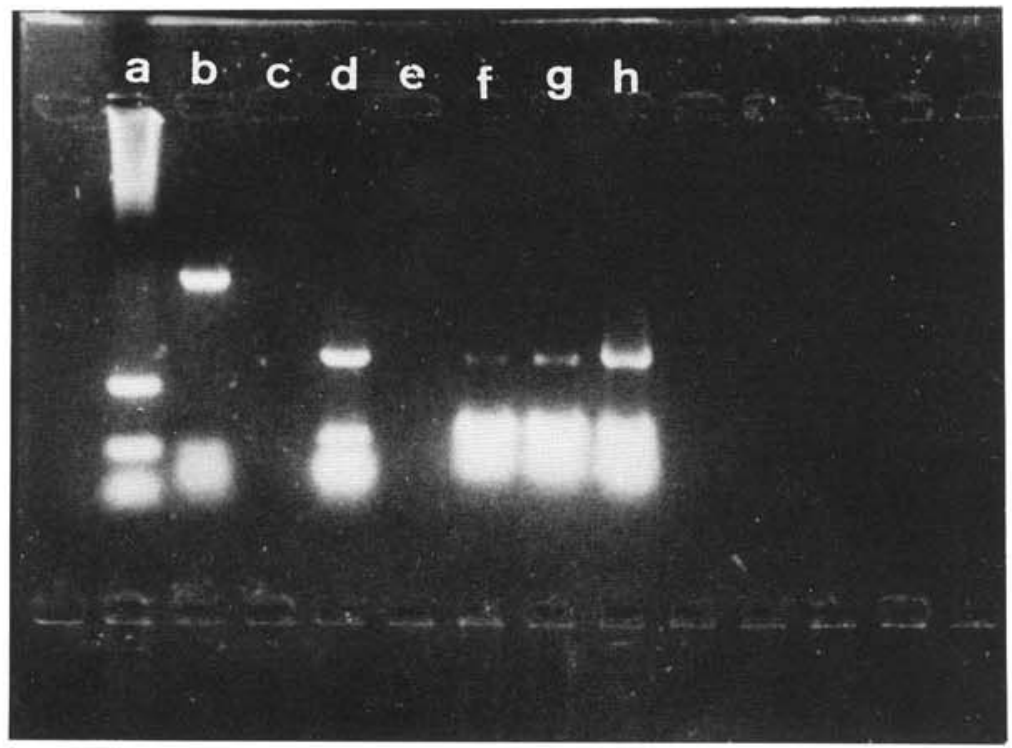

Fig. 1 - Dot-blot hybridization for HIV1+ samples, Positions 11 to 16 are HBV DNA dilutions ( $2 \mathrm{ng}$ to $0.5 \mathrm{pg}$ ), Position $\mathrm{m} 5$ - positive control.

outcome of hepatitis, if HBV infection takes place after HIV infection.

- Identify patients that could benefit from protection through vaccination while still immunocompetent.

- Avoid a possible role of HBV as a cofactor influencing rapid progression to AIDS in HIV infected patients.

\section{RESUMO}

\section{Replicação ativa do vírus da hepatite B (HBV) em doentes infectados pelo vírus da imunodeficiência humana (HIV) de tipo 1 ou de tipo 2}

A fim de avaliar as conseqüências da infecção por HIV no curso da infecção por HBV, ou na imunidade anteriormente adquirida, estudamos um grupo de 66 doentes Caucasóides HIV1+ sintomáticos e outro de 38 indivíduos seropositivos para HIV2 e provenientes da África, quanto a marcadores serológicos de infecção por HBV e quanto à presença de DNA viral circulante, tomada como sinal de replicação ativa do vírus da hepatite.

Os grupos HIV + foram comparados com controles seronegativos adequados tendo-se verificado que $7.6 \%$ dos doentes HIV1+ eram também HBV-DNA+ (versus $3.2 \%$ nos seronegativos) bem como $2.6 \%$ dos HIV $2+$ (versus $2.9 \%$ nos controles seronegativos), não sendo as diferenças estatisticamente significativas em qualquer um dos casos e não tendo sido encontrada correlação entre infecção por HIV e replicação ativa de HBV.

A imunodeficiência que se instala progressivamente após infecção por HIV, poderá ser compatível com um grau de vigilância $T$ suficiente para impedir reinfecção ou reativação de $\mathrm{HBV}$, mesmo em indivíduos já sintomáticos.

Os nossos resultados são relevantes para a escolha de estratégias preventivas da hepatite B em gupos com risco de infecção por HIV.

\section{REFERENCES}

1. BALSANO, C.; BILlET, O.; BENNOUN, M. et al, - Hepatitis B virus $\mathrm{X}$ gene product transactivates HIV-LTR "in vivo". Arch. Virol., 8 (suppl.):63-71, 1993.

2. BARRÉ-SINOUSSI, F.: CHERMANN, J.C.; REY, F, et al, - Isolation of a T lymphotropic retrovirus from a patient at risk for Acquired Immunodeficiency Syndrome (AIDS). Science, 220:868-871. 1983.

3. BONINO, F; HOYER, B.; NELSON, J. et al. - Hepatitis B virus DNA in the sera of HBsAg carriers: a marker of active virus replication in the liver. Hepatology, 1:386-391, 1981.

4. BERTOLETTI, A.; SETTO, A.: CHISANI, F.V. et al. - Natural variants of cytotoxic epitopes are $\mathrm{T}$ cell receptor antagonists for antiviral cytotoxic T cells. Nature, 269:407-410, 1994.

5. BRÉCHOT, C.; HADCHOVEL, M.; SCOTTO. J. et al. - Detection of hepatitis B virus DNA in liver and serum: a direct appraisal of the chronic carrier state. Lancet, 2:765-767, 1981. 

1996.

6. CARMAN, W.F:JACYNA, M:HADZYANNIS, S, et al- - Mutation preventing formation of hepatits $\mathrm{B}$ e antigen in patients with chronic hepatitis B infection. Lancet, 2:588-590, 1989.

7. CDC-Centers for Disease Control - Classification system for human T lymphotropic virus type III / lymphoadenopathy associated virus infection. Ann. intern. Med., 105:234-237, 1986.

8. CISTERNA. R.: CAMPELO, C.; GORRINO, T. et al. - Association between HIV and other DNA virus "in vitro". Eurp. J. clin. Microbiol. infect. Dis., 14:591-596, 1995.

9. CLAVEL. F.: GUYADER, M.; GUÉTARD, D. et al. - Isolation of a new human retrovirus from West African patients with AIDS. Science, 233:343-346, 1986

10. DANE, D.S.; CAMERON, C.H. \& BRIGGS, M. - Virus-like particles in serum of patients with Australia antigen associated hepatitis. Lancet, i: $695-698,1970$

11. DELFINI, C.: GARBUGLIA, A.R.; ALTANI, E. et al. - Heroin addicts infected by HBV and HIV have a low prevalence of HBV DNA in peripheral blood mononuclear cells.J. med. Virol., 41:114-119. 1993

12. DUSHEIKO, G.M.; SHER, R. \& WELLS, C. - Concurrent human immunodeficiency and hepatitis B virus exposition in Southern Africa. In. INTERNATIONAL SYMPOSIUM ON VIRAL HEPATITIS AND LIVER DISEASE, London, 1987. A 30. 11 A

13. FRANCISCID; BALDELI, F; PAPILI, R. et al. - Prevalence of HBV HDV, and HCV hepatitis markers in HIV-positive patients. Europ. J. Epidem., 11:123-126, 1995.

14. GILSON, R.J.: TEDDER, R.S. \& WELLER, 1. - Hepatitis B reactivation or reinfection associated with HIV infection. Lancet, 2:1330, 1989

15. GOLDIN, R.D.; FISH, D.E. HAY, A et al - Histological and immunohistochemical study of hepatitis $B$ virus in human immunodeficiency virus infection. J. clin. Path, 43:203-205, 1990.

16. HOUSSET, C.: POL. S.; CARNOT, F et al. - Interaction between human immunodeficiency virus 1 , hepatitis delta virus and hepatitis B virus infection in 260 chronic carriers of hepatitis B virus. Hepatology, $15: 578-583,1992$

17. ILTIS, J.P.; PATEL, N.M.; LEE, S.R. et al. - Comparative evaluation of an immunofluorescent antibody test, enzyme immunoassay and western blot for the detection of HIV I antibody. Intervirology, 31:122. 128,1990

18. KANEKO, S.: MILLER, R.H.; FEINSTONE, S.M. et al, - Detection of serum hepatitis B virus DNA in patients with chronic hepatitis utilizing the polymerase chain reaction assay. Proc. nat. Acad. Sci. (Wash.), 86:312-316,1989
19. KANEKO, S. \& MILLER, R.H. - Characterization of primers for optimal amplification of Hepatitis B virus DNA in the polymerase chain reaction assay. J. virol. Meth., 29:225-230, 1990.

20. KASHAKA, O. MUBIKAI, L.; KAYEMBE, K et al - Hepatitis B virus activation among Central Africans infected with human immunodeficiency virus (HIV) type I:pre-s2 antigen is predominantly expressed in HIV infection. J. infect. Dis., 169:628-632. 1994.

21. KOBLIN, B.: TAYLOR, P.E.: RUBINSTEIN, P. et al - Effect of duration of hepatitis $B$ virus infection on the association between human immunodeficiency virus type I and hepatitis B viral replication. Hepatology, 15:590-592, 1992

22. LEVRERO, M.; BALSANO, C.: NATOLI, G, et al. - Hepatitis B virus $X$ protein transactivates the long terminal repeat of human immunodeficiency virus type I and 2. Virology, 64:3082-3086, 1990

23. MCDONALD, J,A; CARUSO, L; KARYANIS, P et al - Diminished responsiveness of male homosexual chronic hepatitis B virus carriers with HTLV III antibodies to recombinant $\alpha$-interferon. Hepatology, 7:719-723. 1987

24. McDONALD. J.A.: HARRIS. S.: WATERS, J. et al. - Effect of human immunodeficiency virus (HIV) infection on chronic hepatitis $B$ viral antigen display. J. Hepat., 4:337-342. 1987.

25. SAIKI, R.K.: GEFLAND, D.H.; STOPPER. S.J. et al. - Primer directed enzymatic amplification of DNA with a thermostable DNA polymerase Science, 239:487-491, 1988 .

26. SCOTTO. J.; HADCHOVEL., M.: HEY, C. etal. - Detection of hepatitis $B$ virus DNA in serum by a simple spot hybridization technique Comparison with results for other viral markers. Hepatology, 3:279. 284, 1981

27. TWU, J.S.; WU, J.Y.\& ROBINSON, W.S. - Transcriptional activation of the human immunodeficiency virus type I long terminal repeat by hepatitis B virus X protein requires "de novo" protein synthesis. Virology, 177:406-410, 1990.

28. VENTO, S : DILENI. F; GAROFENO. T: et al, - Reactivation of Hepatits B in AIDS. Lancet, 2:108-109. 1989.

29. WELLER, I.V: FOWLER, M.J.: MONJARDINO, J \& THOMAS. H.C. - The detection of HBV-DNA in serum by molecular hybridisation: a more sensitive method for the detection of complete HBV particles. J. med. Virol., 9:273-280, 1981.

Recebido para publicação em 13/05/1996 Aceito para publicação em 30/09/1996 